\title{
SISI GELAP TOLERANSI BERAGAMA DI SULAWESI UTARA Menyingkap Problem Kerukunan Beragama di Bolaang Mongondow, Bolaang Mongondow Utara dan Kotamobagu
}

\author{
The Dark Side of Religious Tolerance in North Sulawesi \\ Disclosing the Problem of Religious Harmony in Bolaang Mongondow, \\ North Bolaang Mongondow and Kotamobagu
}

\author{
Oleh: Syamsurijal* \\ *Peneliti Pada Balai Litbang Agama Makassar \\ Alamat Kantor: Jl. AP. Pettarani No. 72 Makassar \\ Alamat Email: bhatiialgolfa),email.com
}

\begin{abstract}
Abstrak
Kerukunan beragama menjadi issu penting di Indonesia. Berbagai regulasi dibuat untuk mendukung kerukunan beragama tersebut. Hanya saja asumsi kerukunan beragama yang dianggap berjalan baik di Indonesia temyata hanya mitos belaka. Saat ini beberapa daerah dicekam konflik beragama. Bahkan daerah yang dianggap damai sekalipun temyata menyimpan potensi konflik dan kekerasan agama. Hanya saja daerah-daerah yang selama ini hidup damai seperti Sulawesi Utara, sisi-sisi kekisruhan beragama jarang diangkat kepermukaan. Penelitian ini mengungkap hal tersebut dibalik data indeks kerukunan beragama yang nampaknya memukau. Dengan menggunakan metode kuantitatif di gabungkan penelitian kualitatif, penelitian ini menemukan beberapa sisi gelap toleransi beragama, di kabupaten Bolaang Mongondow, Bolaang Mongondow Utara dan Kotamobagu Sulawesi Utara di balik angka indeks kerukunan beragama yang sangat baik.
\end{abstract}

Kata Kunci: Toleransi, Konflik, Perdamain, Aturan Kerukunan Beragama

\begin{abstract}
Religious harmony is important issues in Indonesia. Various regulations made for the support of religious harmony. Only the assumption of religious harmony is considered to work well in Indonesia was a myth. Currently some areas gripped by religious conflict. Even areas that are considered peaceful though it holds the potential conflict and religious violence. Only areas that had been living peacefully as North Sulawesi, the sides of the religious confusion is rarely raised to the surface. This study reveals that the data behind the index of religious harmony that seems to amaze. By using quantitative methods in combination of qualitative research, this study found some dark side of religious tolerance, in the district Bolaang Mongondow, North Bolaang Mongondow and Kotamobagu, Nort Sulawesi behind the index is very good religious harmony.
\end{abstract}

Keywords: Tolerance, Conflict, Peace, Harmony Religious Rules

\section{PENDAHULUAN}

\section{Mitos Kerukunan; Hanya Pengantar}

$\mathrm{K}$

ata kerukunan beragama hampir menjadi kata sakral di Indonesia, bukan baru sekarang, tapi sejak dari dulu. Bukti pentingnya kerukunan beragama ini, membuat pemerintahan di Indonesia sejak dari zaman kolonial sampai sekarang telah mengeluarkan berbagai peraturan. Hal ini misalnya tercermin dalam stassblad No. 44 tahun 1941 oleh Snouck Hurgronje. Ini direproduksi kembali oleh Presiden Soekarno dengan Penetapan Presiden No. 1 tahun 1965 tentang pencegahan penodaan dan penyalah gunaan agama. Pada masa ORBA Pepres ini ditetapkan menjadi UU no 5 tahun 1969. Meski apa mau dikata, berbagai perturan itu juga menuai kecaman, dianggap bukan sebagai regulasi untuk membangun kerukuanan beragama, namun sebagai peraturan yang justru mengawasi dan mengekang kebebasan beragama. Saat ini kerukunan beragama secara eksplisit baru akan di rancang Undangundangnya. Rencana undang-undang tentang kerukuanan umat beragama ini masuk menjadi prioritas legislasi nasional (prolegnas). Selama ini yang menjadi rujukan mengenai kerukanan umat beragama biasanya adalah Peraturan Bersama Menteri (PBM) antara meneteri dalam negeri dan menteri agama Nomor 8 dan Nomor 9 tahun 2006. Dengan segudang regulasi itu, mahfumlah kita betapa kerukunan beragama begitu penting di Indonesia.

Namun segenap regulasi itu apa boleh buat, tak bergigi sama sekali. Nyatanya saat ini berbagi tindakan 
kekerasan atas nama agama menjadi pemandangan sehari-hari. Penyerangan terhadap kelompok yang berbeda aliran, membunuh orang yang berbeda agama, pembakaran rumah ibadah hadir di depan mata kita. Nyawa manusia menjadi tak berharga dengan dalih membela Tuhan. Kelam, mengerikan dan penuh pergumulan. Sejenak saya tertarik mengutip sebait sajak Matthew Arnold dalam Zen:

"Dan disini kita berdiri di atas dataran kelam

Terombang ambing dalam kengerian, pertarungan dan pergumulan

Kala balatentara bebal yang bertempur di malam buta".'

Bait puisi itu mungkin adalah gambaran dari kehidupan beragama saat ini yang kelam dan penuh dengan pertarungan. Jika masa orde bam, bangsa ini dianggap berada pada tingkat kerukunan beragam yang tinggi, sebenarnya semuanyajuga semu. Sebab saat itu kerukunan dipaksakan dari atas. Maka kerukunan beragama yang terjadi hanya di permukaan. Peraturan yang ada sebagaimana yang telah disebutkan diatas, lebih banyak menjadi alat pemaksa dibanding sebagai sebuah regulasi yang berupaya untuk mengelola keragaman tersebut. Hal ini juga terkait dengan kebijakan secara umum dari pemerintah orde baru dalam mengelola keragaman, termasuk keragaman agama. Meski bermunculan berbagai peraturan yang ditampilkan ke public sebagai perekat dari keragaman tersebut, namun tujuan utamanya adalah penumbuhan identitas bangsa sebagai satu-kesatuan nasional yang integratif. Dalam rangka ini, barangkali sentimen kebangsaan yang lebih sesuai untuk fungsi integratif itu adalah sebagaimana disinyalir oleh Ernest Gellner, terkumpulnya manusia modular yang terintegrasi oleh kultur homogen.

Jika kehidupan keagamaan saat ini berada dalam titik kulminasi konflik, maka kerukunan beragama di Indonesia perlu di amati secara lebih teliti. Tidak hanya di daerah bersumbu pendek (rawan konflik), namun juga daerah yang dianggap aman, dan memiliki toleransi beragama yang cukup kuat. Sebab jika berangkat dari beberapa pengalaman, kerukunan yang hanya mengandalkan regulasi negara, biasanya terjadinya di permukaan. Apalagj saat ini, berbagai daerah di Indonesia berada dalam pusaran globalisasi. Di tengah pusaran globalisasi tersebut, berbagai daerah dengan mudah mengalami pergeseran representasi paham keagamaan dan idiologi. Sebab saat ini amatlah mudah masuknya berbagai paham dan idiologi baru dari satu Negara ke Negara lain.

Penelitian ini mencoba untuk melihat lebih jauh persoalan kerukunan yang berdasar pengalaman hanya menjadi mitos belaka. Daerah yang dipilih adalah Sulawesi Utara yang selama ini dianggap sebagai salah satu daerah yang tingkat toleransinya cukup tinggi. Dalam satu tulisan Anita Deka dikemukakakan bahwa Di Sulawesi Utara khususnya Kota Manado merupakan daerah yang multikultural dimana beragam agama, suku, dan budaya yang telah menjadi realita dikota Manado, namun di tengah keragaman tersebut, penduduk Sulawesi Utara bisa menjalin hubungan toleransi dengan orang yang berbeda agama.

Meski penelusuran dilakukan di daerah Sulawesi Utara, namun penelitian ini akan lebih focus menguraikan pada tiga kabupaten, yaitu Bolaang Mongondow, Bolaang Mongondow Utara dan Kotamobagu. Namun tentu saja secara umum Sulawesi utara juga akan dilihat tingkat kerukunannya. Untuk melihat hal itu, maka pertama-tama terlebih dahulu melihat indeks kerukunannya, lalu mencoba mendalami dibalik munculnya angka-angka indeks tersebut. Yang terpenting juga adalah mencoba memunculkan apa yang tidak terkatakan oleh angka. Dengan demikian permasalah pokok dari penelitian ini adalah: 1). Sejauh mana indeks kerkunan beragama di tiga tempat tersebut dan 2). Bagaimana potret kerukunan beragama di balik nilai indeks kerukunan beragama?

\section{Metode Penelitian}

Penelitian ini menggunakan metode kuantitatif yang digabung dengan metode kualitatif. Metode kuantitatif digunakan untuk menemukan nilai indeks kerukunan beragama, sedangkan kualitatif digunakan untuk mendalami potret kerukunan dibalik angkaangka indeks tersebut dan juga yang tidak terungkap pada nilai-nilai indeks. ${ }^{3}$

\footnotetext{
'Amatya Sen. 2006, Identity and Violence: The Hussion ofDestiny. New York : Norton in Company.h , xxiv

'Anita Deka , 2008. Manado Monumen Pluralisme Agama. httD://anitadeka,wordpress,com

${ }^{3}$ Rumus yang digunakan untuk penentuan indeks adalah:

IKUB = Jumlah Total Nilai Jawaban

Nilai Terbaik (Jumlah Pertanyaan (34) x Jumlah Responden x 4)

Selanjutnya IKUB ini akan dilihat berada pada criteria mana (sangat buruk, buruk, baik atau sangat baik). Adapun criteria itu :0.01 - 0.25 SANGAT BURUK, $0.26-0.50$ BURUK, $0.51-0.75 \rightarrow$ BAIK , 0.76 -1.00 * SANGAT BAIK.
} 


\section{PEMBAHASAN}

\section{Tiga Daerah yang Bermula Dari Bolaang Mongondow}

Ketiga kabupaten yang menjadi lokasi penelitian ini awalnya bermula dari kabupaten Bolaang Mongondow. Daerah inilah yang menjadi awal dari semuanya, lalu mekar menjadi beberapa kabupaten. Diantaranya menjadi Bolaang Mongondow Utara dan Kota Mobagu. Itulah sebabnya Bolaang Mongondow sekarang acap kali pula disebut dengan Bolaang Induk. Hanya saja ketika Bolaang Mongondow dimekarkan lagi menjadi Kotamobagu, ibukota Bolaang Mongondow induklah yang harus bergeser ke daerah Lolak.

Karena itu sebelumnya, kita mundur sejenak kebelakang untuk melihat sejarah munculnnya Bolaang Mongondow ini. Bolaangg Mongondow berasal dari keturunanGumalangjt danTendeduata sertaTumotoibokol dan Tumotoibokat, awalnya mereka tinggal di gunung Komasaan (Bintauna). Kemudian menyebar ke timur di tudu in Lombagin, Buntalo, Pondoli', Ginolantungan sampai ke pedalaman tudu in Passi, tudu in Lolayan, tudu in Sia', tudu in Bumbungon, Mahag, Siniow dan lain-lain. Peristiwa perpindahan ini terjadi sekitar abad 8 dan 9. Nama Bolaangg berasal dari kata "bolango" atau "balangon" yang berarti laut. Bolaangg atau golaang dapat pula berarti menjadi terang atau terbuka dan tidak gelap, sedangkan Mongondow dari kata 'momondow' yang berarti berseru tanda kemenangan.

Menuju ketiga daerah ini, jika memulai perjalanan dari Menado, bisa ditempuh satu arah. Meski khusus untuk Kota Mobagu, jika sudah masuk kedaerah Bolaang, harus ditempuh dengan jalur sendiri. Sementara dua daerah lainnya, yaitu Bolaang Mongondow dan Bolaang Mongondow Utara melalui jalur yang sama. Jalur tersebut adalah jalur trans ke Gorontalo. Ketiga daerah ini memiliki tipikal geografis yang hampir sama. Daerah pertanian dan nelayan. Namun untuk daerah Bolaang Mongondow Utara, banyak orang-orang yang bekerja sebagai karyawan. Demikian halnya di Kotamobagu, khususnya di kota lebih banyak yang berprofesi karyawan, pedagang dan pegawai. Khususnya daerah Bolaang Mongondow induk, di daerah ibukota kabupaten yaitu di kecamatan Lolak, masyarakatnya adalah nelayan.
Kabupaten Bolaang Mongondow sendiri luas areanya adalah $\mathbf{3 . 5 0 6 , 2 4} \mathbf{k m}^{2}$. Di Bolaang Mongondow ini ada beberapa kecamatan di antaranya: Dumoga Bar at, Dumoga Utara, Dumoga Timur, Lolayan, Passi Barat, Passi Timur, Bolaangg, Bolaangg Timur, Lolak,*\$ang Tombolang, Bilalang, Poigar. Ibu kota Bolamongondow adalah Lolak. Di Lolak sendiri ada 22 desa.'

Kabupaten Bolaang Mangondow Utara mempunyai luas wilayah 1.843,92 km2, beribukota di Boroko Kecamatan Kaidipang. Jumlah Kecamatan ada 6 (enam) Kecamatan yaitu: Pinogaluman, Kaidipang, Bolaangg Itang Barat, Bolaangg Itang Timur, Bintauna dan Sangkub. Kabupaten Bolaangg Mongondow Utara merupakan salah satu daerah yang baru dimekarkan di Provinsi Sulawesi Utara yang disahkan melalui Undang-Undang No 10 Tahun 2007. ${ }^{6}$

Jumlah Penduduk di Bolamongondow adalah 219.572 dengan laki-laki sekitar 116.310 dan perempuan sebanyak 103.262. Jika didasarkan pada agama, maka komposisi penduduk menjadi:

1. Laki-laki: Islam 67.828, Kristen 40.633, Katolik 1.721 , hindu 6.121 orang dan Budha 7 orang.

2. Perempuan: Islam 60.203, Kristen 36.086, Katolik,1.579, Hindu 5.390, Budha 5. Jumlah keseluruhannya adalah Islam 128.030, Kristen 76.719, Katolik 3.300, Hindu 11.511 dan Budha ada 12 orang.

Kabupaten Bolaang Mongondow Utara sedikit berbeda dengan Bolaang Mongondow induk, di kabupaten ini hanya dua agama yang dominan yaitu Islam dan Kristen. Untuk jelasnya komposisi penduduk berdasarkan agama sebagai berikut: Islam berjumlah 62,045 , Kristen berjumlah 8,889, Katolik ada 22 dan Hindu hanya 4. Meski untuk agama di dominasi oleh dua agama tadi, namun dari segi etnis cukup beragam. Di kabupaten ini ada etnis Sanger, etnis Jawa, etnis Minahasa, etnis Gorontalo, etnis Bugis dan etnis Mongondow. Jika pada etnistas, masyarakatnya cukup berbaur, tidak demikian halnya dengan agama. ${ }^{8}$

Untuk kabupaten Kotamobagu jumlah penduduk sekitar 99.519 jiwa dengan komposisi pemeluk agama

\footnotetext{
"Kotamobagu dalam angka 2010 juga bisa dilihat dalam Bolaangmongondow dalam angka 2010.

s Bolaang Mongondow dalam angka 2010

- Bolaang Mongondow Utara dalam angka 2010

BPS Bolaang Mongondow, loc.cit.

${ }^{\circledR}$ BPS Bolaang Mongondow Utara, loc.cit
} 
dominan Islam dimana $77 \%$ penduduk Kota ini memeluk agama Islam, 19\% Protestan, 2,43\% Katolik, Hindu dan budha masing-masing $1 \%$ dan $0,31 \%$. Adapun Etnik yang berada di daerah ini antara lain: Bolaang Mongondowg mencapai 67,11\%, diikuti etnik Minahasa 13,49\%, Gorontalo 5,95\%, Sangir 3,01\% dan Jawa $2,44 \%$.

Problem utama dari tiga kabupaten adalah segregasi penduduk berdasarkan agama. Hal ini sewaktu-waktu bisa menjadi factor yang semakin mempermulus konflik. Hal inilah yang dapat kita lihat selanjutnya pada kasus-kasus yang terjadi, khususnya di kabupaten Bolaang Mongondow.

\section{Sulut Sulit di Sulut Konflik; Hanya Mitos?}

Sulawesi Utara atau Sulut menjadi salah satu daerah primadona di kepulauan Sulawesi, bahkan di Indonesia Timur. Meminjam istilah Parry, Sulawesi Utara ibarat berada di lengan yang terayun atau melambai dari kepulaaun ini'. Seakan lambaian tangan itu memanggil orang kesegenap penjuru untuk datang berkunjungke daerah ini. Secara geografis daerah ini cukup strategis, sebab ia memiliki daerah dengan daratan yang subur dan lautan yang kaya dengan sumber daya alam. Di daerah ini memiliki pulau-pulau dengan berbagai kekayaan alam yang indah dan menakjubkan. Bunaken adalah salah satu contohnya, dengan keindahan bawa laut yang menyihir dan mengundang orang datang di Sulawesi Utara. Tapi Tentu saja bukan semata karena daerah ini memiliki beberapa tempat wisata, namun kondisi daerah Sulawesi Utara yang dianggap tenang, tentram jauh dari konflik membuat posisi strategisnya itu semakin menarik orang datang ke daerah ini. Adagium yang menyatakan Sulut sulit di sulut ternyata ikut menndorong para pendatang untuk beramai-ramai mengunjungi daerah ini.

Lantas benarkah daerah ini, sulit untuk mengalami konflik karena masyarakatnya rukun dan damai, khususnya dalam hubungan keagamaan? Janganjangan adagium itu hanya mitos belaka. Untuk sementara jika melihat eskalasi konflik yang cukup rendah, apalagi konflik agama dan juga berdasarkan keterangan beberapa pemuka agama, maka mungkin adagium itu ada benarnya. Apalagi jika dilihat indeks kerukunan beragama daerah ini berdasarkan penelitian yang kami lakukan berada pada nilai yang sangat memuaskan.

Khusus untuk tiga daerah (Bolaang Mongondow, Bolaang Mongondow Utara dan kotamobagu) yang menjadi focus penelitian ini di temukan indeks kerukunan umat beragama berada pada nilai yang sangat bagus yaitu 0,78 untuk Bolaang Mongondow, 0,79 untuk Bolmon Utara dan 0,79 untuk Kotamobagu.

\section{Grafik 1}

\section{Indeks Kerukunan Beragama Tiga Kabupaten}

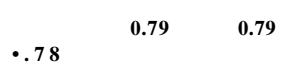

Salmon Bolmon Utara Kotamobagu

Jika ketiganya digabung dalam satu zona, maka indeks kerkunan beragama berada pada titik $\mathbf{0 , 7 8}$. Dengan demikian berada pada kategori sangat baik. Indeks kerukunan beragama di tiga daerah ini untuk sementara mengkonfirmasi asumsi Sulawesi Utara yang dianggap memiliki tingkat kerukunan beragama yang baik. George ED Tanor, Kepala Balitbanda Bolaang Mongondow memperjelas hal ini. Menurutnya dalam perayaan-perayaan keagamaan, biasanya antara umat beragama saling menjaga. Jika idul fitri, umat dari agama lain ikut menjaga keamanan, agar hari raya tersebut berlangsung dengan baik. ${ }^{10}$ Hal yang sama disampaikan juga oleh Kepala Departemen Agama Kotamobagu, bahwa penghormatan antara penganut agama yang berbeda nampak pada berbagai acaraacara formal yang dilakukan, khususnya yang dilakukan oleh pemerintah daerah.

Namun tentu saja ini masih perlu dipertanyakan. Benarkah regulasi tentang kerukunan umat beragama yang ada saat ini serta kearifan lokal yang dimiliki daerah bersangkutan ikut mempengaruhi kerukunan beragama yang indeksnya sangat baik ini? Lalu apakah dengan indeks kerukunan agama yang tinggi ini mencerminkan bahwa konflik agama tidak mungkin terjadi lagi di ketiga daerah ini? Pertanyaan yang lain, indeks kerukunan beragama ini menggambarkan tingkatan yang mana, apakah inklusivisme, toleransi passif, toleransi aktif atau sudah berada pada tataran pluralisme?

\footnotetext{
'Party menggambarkan kepulaaun di Indonesia dengan sedikit aneh; sumatera yang tambun, Jawa yang ringkas, Kalimantan yang dibelah garis khatulistiwa dengan Kejam dan Sulawesi yang digambarkannya sebagai pulau semenanjung dengan tangan melambai bak acrobat. Di tangan yang melambai itulah Sulawesi Utara berada. Lihat Richard Liloyd Parry. 2005, In the Time of Madness; Indonesia on the Edge of Chaos. New York : Grove Press, h. 25

'10 Wawancara ED Tanor tanggal 20 September 2011
} 
Untuk menjawab pertanyaan-pertanyaan tersebut, kita perlu mendeteksi indeks tiap-tiap variabel dalam penelitian ini, Untuk jelasnya kita lihat pada grafik dibawahini:

\section{Grafik 2 \\ Indeks Tiap Variabel di tiga kabupaten}

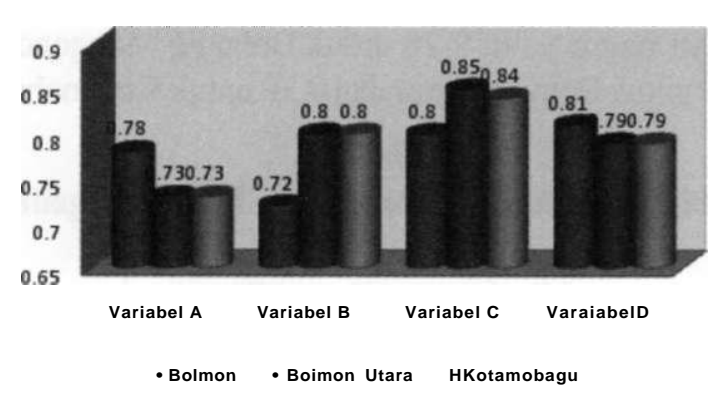

Dari grafik di atas nampak bahwa:

Variabel A atau variable Hubungan Sosial, Toleransi, Kerjasama dan Komunikasi, nampak bahwa Bolaang Mongondow indeksnya adalah 0, 78, atau berada pada kategori sangat baik, sementara Bolaang Mongondow Utara dan Kotamobagu hanya berada pada kategori baik. Perbedaan ini tidak signifikan. Namun ini menunjukkan bahwa komunikasi atau hubungan social di daerah Bolaang Mongondow induk lebih baik daripada dua daerah lainnya. Hanya saja komunikasi dan hubungan social itu, untuk ketiga daerah nampaknya sama dalam hal, bahwa itu terjadi dalam hubungan formal saja. Artinya hubungan komunikasi dan hubungan social lainnya terjalin pada saat ada acara-acara formal yang diadakan oleh agama tertentu atau oleh pemerintah. Hal ini dipertegas oleh Subekti kepala kementerian agama Bolaang Mongondow, menurutnya relasi yang terbangun antara penganut agama sebenarnya bersifat formal, hanya terjadi ketika ada kegiatan yang dilakukan pemerintah." Pada saat itu, demikian biasanya baru ada komunikasi antara penganut agama. Bahkan dalam acara semacam itu biasanya yang memberikan sambutan akan memberikan salam dari berbagai versi salam agama. Di akui oleh Subekti, dalam kehidupan sehari-hari antara sesama pemeluk agamajarang saling mengunjungi. Untuk elitelit beragama, dialog memang sering dilakukan namun menurutnya hal itu terjalin secara formal.

Komunikasi dan hubungan formal antara penganut agama ini juga bisa dimaknai bahwa komunikasi tersebut hanya terjalin pada saat di kantor. Hubungan social dan komunikasi semacam ini bisa dipengaruhi oleh segregasi penduduk yang berdasarkan agama. Karena penduduk yang tinggal sekampung dominan berasal dari agama yang sama, maka dalam kehidupan sehari-hari mereka hanya berkomunikasi dengan penduduk yang seagama. Hal ini nampak sekali di beberapa kecamatan Bolaang Mongondow, seperti Dumongga Barat dan Timur.

Hubungan penganut agama semacam ini mungkin bisa nampak bagus, tapi hanya pada tataran permukaan. Hal ini lazim disebut dengan iklusivisme atau toleransi pada tataran passif. Penganut agama yang satu bisa mengasumsikan bahwa kebenaran bisa pula ada pada yang lain tetapi masih menyatakan yang tertinggi adalah agama yang dianut. Persoalannya tidak selesai disitu, namun juga prinsip ini biasanya tidak mampu mendorong keinginan untuk menjalin interaksi yang lebih dalam. Prinsip agamamu adalah agamamu dan agamaku adalah agamaku kental dalam hubungan semacam ini. Yang menonjol dari sikap semacam ini adalah menerima keragaman sebagai sesuatu yang factual. Artinya mereka sadar bahwa orang diciptakan berbeda, maka tidak ada pilihan kecuali toleran terhadap orang lain yang berbeda tersebut.

Problem terbesar dari hubungan semacam ini adalah tidak bisa meretas rasa curiga antara satu dengan yang lain. Demikian halnya tidak bisa menghilangkan dominasi agama tertentu yang mayoritas terhadap yang lain. Jika merujuk pada Walzer, maka pola hubungan semacam ini hanya memenuhi dua subtansi toleransi yaitu menerima perbedaan untuk hidup damai dan menerima bahwa orang lain juga memiliki hak. ${ }^{12}$ Ada 3 hal penting lainnya yang tidak terpenuhi yaitu mengesperesikan keterbukaan terhadap yang lain, dukungan penuh terhadap perebedaan dan ingin belajar serta mendengarkan dari orang lain.

Dengan demikian, kerukunan umat beragama semacam ini, bolehjadi tidak menjadi pengalamanhidup sehari-hari. Bahkan sangat boleh jadi kerukunan semacam ini masih merupakan imbas perukunan masa orde baru. Perukunan berbeda dengan kerukunan, sebab kata yang pertama adalah sebuah proses pemaksaan rukun demi stabilitas nasional. Cara ini

\footnotetext{
"Wawancara Subekti Tanggal 22 September 2011.

${ }^{12}$ Michael Walzer, 1997. On Toleration. Yale University Press : New Haven and London
} 
biasanya dengan menggunakan model meelting pott, yaitu satu proses peleburan identitas. Semua identitas primordial (termasuk agama) dihilangkan dan lebur masuk ke dalam identitas nasional. Cara ini biasanya berhasil sejauh stabilitas politik mapan, namun akan mulai terkoyak-koyak jika politik mulai goncang. Padahal Amy Gutmaan secara tegas menyatakan identitas keagamaan (primordial) yang ingin muncul tidak selalu harus ditekan, karena itu tidak selamanya bertentangan dengan demokrasi. Sejauh bertumpu pada aturan hokum yang baik, makajustru bisa sejalan belaka. ${ }^{13}$

Adapun dua daerah, yaitu Bolaang Mongondow Utara dan Kotamobagu yang lebih rendah indeksnya pada variable Hubungan Sosial, Toleransi, Kerjasama dan Komunikasi dipengaruhi oleh rendahnya indeks beberapa indicator. Selengkapnya kita lihat pada grafik di bawah ini:

\section{Grafik 3}

\section{Perbandingan Indikator Variabel Hubungan Sosial Pada Dua Kabupaten dengan Indeks Terendah}

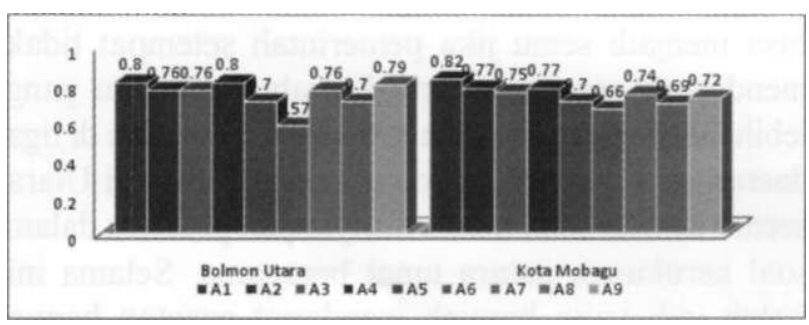

Jika kita perhatikan pada grafik, maka nampak untuk konteks Bolaang Mongondow Utara, indicator terendah untuk variabel A (Hubungan social, Toleransi dan Komunikasi) adalah A6 (memberikan bantuan pada penganut agama lain), Indeks hanya 0,57 . Ini meskipun masih berada pada kategori baik, namun ini mempengaruhi rendahnya variabel A pada kabupaten Bolaang Mongondow. Pada masyarakat Bolaang Mongondow Utara ini, meski masih mau berkomunikasi, namun banyak yang mulai tidak rela jika sudah harus membantu pembangunan rumah ibadah orang yang berbeda agama. Ini semakin mempertegas bahwa hubungan yang terbangun, hanyalah hubungan formal di permukaan, belum menjadi pro eksistensi. Hal yang sama terjadi pada kabupaten Kotamobagu, Indikator terendah pada variabel A adalah A6 dengan indeks 0,66.

Selanjutnya untuk varibel B (Arogansi Agama, Konflik dan resolusi Konflik), ada dua kabupaten tidak mencapai kategori sangat baik, yaitu Bolaang Mongondow (induk) Untuk jelasnya kita lihat indeks tiap indicator pada variabel B di dua kabupaten tersebut.

\section{Grafik 4}

Perbandingan Variabel Arogansi dan Konflik Pada Kabupaten dengan Indeks Terendah

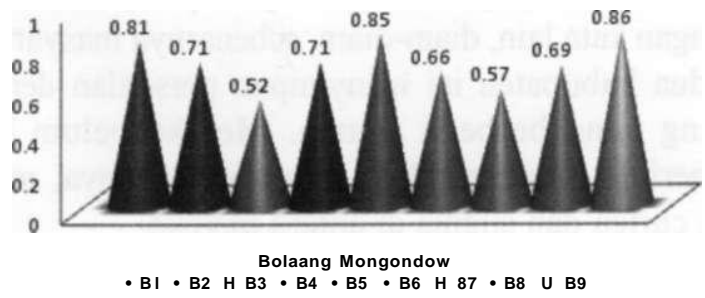

Untuk daerah ini, yaitu Bolaang Mongondow indicator terendah untuk variabel B (Arogansi dan Konflik), ada pada indicator B3 (Persoalan Politik dan kekuasaan pemicu utama lahirnya konflik). Hal ini di di dasari oleh pengalaman kabupaten ini dalam soal konflik. Pada dua daerah ini, konflik yang terjadi selama ini tidak pernah dipicu oleh persoalan politik. Konflik biasanya terjadi akibat perkelahian antara anak muda yang kemudian meluas menjadi perkelahian kampung. Pada kasus yang terjadi di Bolaang Mongondow induk, khususnya di kecamatan Dumongga Timur, konflik yang pernah terjadi pada tiga tahun terakhir ini diakibatkan oleh perebutan terhadap sumber daya alam. Perebutan lahan tambang yang ada di daerah Dumongga ini, akhirnya merambat pada perkelahian antara kampung Toroakan dan Pesian.

Persoalannya kemudian apakah konflik, yang kalau dilihat sepintas berlatar perebutan resource ekonomi dan perkelahian anak muda, tidak merambat menjadi persoalan agama? Pertanyaan yang tidak kalah pentingnya, betulkah ekonomi dan perkelahian penduduk adalah akar dari konflik atau hanya sekedar pemicu saja?

Jika merujuk pada penjelasan Subekti, kepala Kementerian agama Bolaang Mongondow, konflik Torakan dan Pesian yang berefek pada pembakaran 25 rumah di Torakan dan 7 rumah di Pesian, sudah mengarah pada konflik agama. Kelompok yang bertikai mengindentifikasi diri pada Islam dan Kristen. Bahkan Torakan yang dominan Islam dikepung dua kampong yang penduduknya dominan Kristen. ${ }^{14}$ Ini menujukkan bahwa konflik yang dipicu oleh persoalan-persoalan diluar agama, bisa berujung pada konflik agama.

\footnotetext{
${ }^{13}$ Amy Gutmann. 2003, Identity in Democracy. New Jersey: Princeton University Press, h. 168-191.

" Wawancara Subekti Tgl 22 September 2011
} 
Satu soal juga masih menyisakan tanya, benarkan konflik ini hanya disebabkan factor perebutan sumber daya alam, atau ada hal laten lainnya yang sebenarnya tinggal menunggu pemicunya saja. Jika kita melihat segregasi penduduk yang di dasarkan agama, lalu komunikasi antara penganut agama yang hanya di tataran formal saja maka sesungguhnya persoalan agama di daerah ini bisa menjadi persoalan laten. Dengan kata lain, diam-diam, sebenarnya masyarakat di dua kabupaten ini menyimpan persoalan dengan orang yang berbeda agama. Mereka belum bisa menerima satu sama lain secara sepenuhnya, masih ada curiga dan stigma di antara mereka.

Jika demikian adanya maka ini hanya menunggu waktu saja. Apalagi jika pergerakan penduduk dari luar ke daerah ini juga semakin besar. Key Deaux dan Shaun Wiley dalam Gail Moloney (2007), pernah menyebut adanya moving people dan shifting representation.

Dalam konteks itu. Deaux dan Wiley menekankan bahwa pergerakan sekolompok orang dari negara atau tempat tertentu ke tempat yang lain akan merigakibtkan perubahan populasi dalam satu tempat yang pada akhirnya melahirkan pergeseran representasi. Woodward (2007) menyatakan moving people and shifting representation ini juga melahirkan pergerakan idiologi baru ke tempat tertentu khususnya paham keagamaan. ${ }^{16}$ Inilah yang bisa memicu, bergesernya cara-cara orang merepresentasikan diri yang pada akhirnya merubah cara orang memandang yang lain.

Untuk Varibel C (Kebijakan pemerintah) tiga kabupaten nampaknya berada pada indeks yang sangat baik. Namun tentu saja kita tidak bisa mengatakan bahwa regulasi atau kebijakan pemerintah saat ini sudah di terima oleh masyarakat dalam pengelolaan kerukunan. Soalnya PBM No 8 dan 9 saat ini masih menuai kontroversi dan penolakan di tengah masyarakat, khususnya yang terkait dengan syarat pendirian rumah ibadah yang harus memiliki jamaah 90 orang dan disetujui oleh 60 masyarakat di lingkungan tersebut. Hal ini dianggap membatasi masyarakat dalam mendirikan rumah ibadah mereka. Namun yang jelas berdasarkan respon dari responden, masyarakat menganggap bahwa untuk menjaga kerukunan beragama kebijakan pemerintah tetap dibutuhkan.
Untuk Variabel D (Peran organisasi masyarakat dan Kearifan Lokal), diantara ketiga kabupaten, semuanya baik. Secara umum dapat kita katakana bahwa kearifan local berkontribusi terhadap kerukunan beragama. Di ketiga daerah ini, Bolaang Mongondow, Bolaang Mongondow Utara dan Kotamobagu memang dikenal kearifan local yang mendorong pada kehidupan bersama dalam perbedaan, diantaranya satu ujar-ujar yang cukup menarik "o moto totompiaan, moto tabian, bo moto tanoban". Ujaran tersebut bermakna baku baik-baik, baku sayang dan baku inga'."

Hanya saja kearifan local yang berupa ujaran itu harus di dorong menjadi bagian dari praktek kehidupan sehari-hari. Bukan sekedar ujaran yang hanya tinggal dalam memory masyarakat.

\section{PENUTUP}

Dari uraian di atas, nampaknya indeks kerukunan beragama yang sangat baik di tiga daeah, yaitu Bolaang Mongondow, Bolaang Mongondow Utara dan Kotamobagu menyimpan sisi gelap. Kerukunan yang tercipta berada pada aras permukaan. Kerukunan ini bisa menjadi semu jika pemerintah setempat tidak mendorong secara cultural kearah kerukunan yang lebih mendalam dan subtantif. Hasil penelitian di tiga daerah ini juga menunjukkan bahwa Sulawesi Utara secara keseluruhan masih menyimpan problem dalam soal kerukunan antara umat beragama. Selama ini boleh jadi yang banyak mendapat sorotan hanya ibukota provensi yaitu Menado. Dari sana lalu muncul kesimpulan daerah Sulawesi Uatara adalah daerah yang rukun dan damai. Padahal di sudut-sudut daerah ini, di tempat yang berada di pelosok, ternyata kerukunan masih menjadi problem tersendiri.

Dari temuan-temuan tadi maka yang yang perlu digaris bawahi adalah meski secara indeks, kerukunan beragama ketiga daerah tersebut berada pada kategori sangat baik $(0,77)$, namun terlihat bahwa kerukunan yang terjalin, khususnya dalam konteks komunikasi dan hubungan social, nampaknya berjalan di tingkat formal atau permukaan. Model hubungan semacam ini juga bisa mendukung kerukunan namun menyimpan persoalan. Persoalan itu terkait dengan masih mengendapnya perasaan saling mencurigai dan stigma antara satu dengan lainnya Yang fatal, meski prespektif masyarakat tidak mendukung adanya konflik, namun

\footnotetext{
${ }^{15}$ Gail Moloney and Ian Walker. 2007, Social Representation and Identity: Content, Process and Power. New York : Palgrave Macmilan

${ }^{16}$ Kathryn Woodward. 1997, Identity and Difference. London : SAGE Publication

17 Wawancara dengan Remon Tanggal 22 September 2011.
} 
dalam realitas apa boleh buat kenyataannya kurang menggembirakan. Konflik nyatanya masih terjadi. Yang meski dipicu dengan soal-soal yang berasal dari luar agama, namun hal ini bila tidak ditangani dengan baik akan mengarah pada konflik agama. Hal ini disebabkan karena adanya persoalan laten dalam hubungan social yaitu rasa saling mencurigai dan perasaan dominasi satu kelompok (agama) terhadap lainnya. Tak kalah pentinya untuk kita catat bersama adalah peran-peran institusi local maupun kearifan local yang ada. Selama ini, diasumsikan bahwa institusi local maupun kearifan local cukup berperan secara efektif dalam mendukung kerukunan umat beragama. Namun soalnya bukan di situ,tetapi apakah kearifan lokal yang ada di daerah ini masih menjadi bagian dari parktek kehidupan seharihari atau hanya sekedar slogan yang muncul saat pidato. Jika ia sudah tidak menjadi bagian dari praktek hidup masyarakat, maka ada saatnya kearifan local tersebut menjadi tidak berarti sama sekali.

Realitas ini mengharuskan adanya tindakan nyata dari Pemerintah dan Masyarakat untuk mencegah konflik yang masih sangat mungkin terjadi, dengan melakukan: pertama, tindakan pencegahan dengan membuat aturan yang jelas terhadap kemungkinan masuknya paham-paham baru keagamaan yang bisa mengubah cara masyarakat merepresentasikan diri. Kedua, Mewaspadai konflik yang berbasis ekonomi dengan melakukan pengaturan yang jelas terhadap reseource ekonomi di satu daerah. Ketiga, meningkatkan dialog antara umat beragama di level grass root dan tokoh-tokoh agama di tingkat jamaah. Bukan lagi dialog formal tokoh-tokoh agama di tingkat kabupaten. Hal ini bisa dilakukan dengan mengembangkan FGD kampung, atau FGD lintas kampung dengan topik-topik social, basis dialog ini bisa pada kearifan local yang sudah ada.

Kita berharap semoga kerukunan di Sulawesi Utara bukan hanya sekedar mitos, sebagaimana mitos yang dibangun oleh pemerintah orde baru. Karenanya segenap sisi gelap dari kerukunan beragama di daerah ini perlu kita singkap seterang-terangnya, meski apa boleh buat pada akhirnya kita akan memperlihatkan 'borok-borok' dari kerukunan tersebut. Tapi hanya dengan cara itulah borok-borok kerukunan tersebut dapat kita sembuhkan.

\section{Ucapan Ten ma Kasih}

Penelitian ini tidak terlaksana tanpa bantuan beberapa pihak. Karena itu, ucapan terima kasih saya sampaikan kepada Kementerian Agama Bolaang Mongondow dan Ibu Essy staf balitbanda atas bantuannya selama penelitian.

\section{DAFTAR PUSTAKA}

Bolaang Mongondow dalam angka 2010

Bolaang Mongondow Utara dalam angka 2010

Deka, Anita, 2008. Manado Monumen Pluralisme Agama. http:/ lan itadeka. wordpress. com

Gutmann, Amy 2003, Identity in Democracy. New Jersey: Princeton University Press, h. 168-191.

Kotamobagu dalam angka 2010

Moloney, Gail and Ian Walker. 2007, Social Representation and Identity: Content, Process and Power. New York : Palgrave Macmilan

Parry, Richard Liloyd. 2005, In the Time of Madness; Indonesia on the Edge of Chaos. New York : Grove Press, h. 25

Sen, Amatya. 2006, Identity and Violence: Thellussion of Destiny. New York : Norton in Company.h, xxiv

Walzer, Michael. 1997. On Toleration. Yale University Press : New Haven and London

Woodward Kathryn. 1997', Identity and Difference. London: SAGE Publication

\section{Wa wan cara}

Wawancara dengan Remon Tanggal 22 September 2011.

Wawancara ED Tanor tanggal 20 September 2011

Wawancara Subekti Tanggal 22 September 2011. 